\author{
Yelyzaveta G. Koniaieva \\ V.N. Karazin Kharkiv National University, Department of Foreign Economic Relations and Touristic Business \\ 4 Svobody Sq., 61002 Kharkiv, Ukraine, sunnybigday@gmail.com \\ Vitalina A. Babenko \\ V.N. Karazin Kharkiv National University, Department of Foreign Economic Relations and Touristic Business \\ 4 Svobody Sq., 61022 Kharkiv, Ukraine, vitalinababenko@karazin.ua \\ (D) https://orcid.org/0000-0002-4816-4579
}

\title{
DETERMINING PRIORITIES OF SCIENTIFIC AND TECHNICAL COOPERATION BETWEEN UKRAINE, THE EU AND CHILE IN THE FIELD OF NON-CONVENTIONAL RENEWABLE ENERGY SOURCES
}

\begin{abstract}
As many programs of scientific and technical cooperation of various fields are being successfully implemented between Ukraine and the EU, the author has set the goal of intensifying relations between Ukraine and Chile in the field of green energy. The cooperation Ukraine has had with the EU serves as an example of future cooperation between Ukraine and Chile. The text explores Chile's experience in the field of green energy and, through the comparative example of such cooperation between Ukraine and the EU countries, shows that such interaction is a worthwhile endeavor. Based on an analysis of research materials, one of the priority areas of scientific and technical cooperation is the use of non-traditional renewable energy technologies. In Ukraine, and the EU, as well as Chile, there are objective factors (natural, resources, socio-economic, environmentaltechnological) that concern their development. It is interesting to note Ukraine's scientific experience and implementation of these technologies and the organizational and economic support of them as priorities in the context of national and regional policy. All aspects of international scientific and technical cooperation, including through the exchange of intellectual products, make it possible to increase the effectiveness of forms of state support, the innovation, production and business activities of Ukraine and the corresponding development of producers and consumers' motivation towards using non-conventional forms of renewable energy technology.
\end{abstract}

\section{Key words}

Cooperation between Ukraine and the EU, scientific and technical cooperation between Ukraine and Chile, nontraditional renewable energy, innovative susceptibility.

\section{Introduction}

The chosen priorities of international scientific and technical cooperation influence economic development of the global economy. With the continued emergence and development of the global economy, scientific and technical cooperation is constantly broadening and acquiring new forms. However, when implemented, such cooperation becomes a relatively independent phenomenon that obeys its own laws and which have their own specifics in realizing the potential of international economic relations in general [1]. This is one of the active forms of international economic relations, which determines the growing dynamics in modern conditions and international scientific and technical cooperation. This is an intangible form of economic relationships and conditions through the mutually beneficial exchange of scientific and technical knowledge, intellectual property, experience and programmes of scientific and technical development, engineering services, etc. Together, this plays an increasing role in the intensification of scientific development and production of the subjects of world economic relationships.

\section{Related work}

The research analysis indicates significant attention paid to the problem of establishing priorities for the development of scientific and technical cooperation within the framework of international economic relations. The topic was actively studied and developed by many prominent academics such as Sidorov V. [2, 6], Babenko V. [3, 4, 5], Matyushenko I. [7] and others. The field of non-conventional energy source technologies in the process of effective global and domestic development has been studied by academics such as Dyuzhev V. [8], Voitko S. [9], Dzhedzhula V. [10] and Vytvytska O. [11], Matyushenko I. [12] and others. However, taking into account each state's objective conditions and the needs and prospects for their scientific and technological development, a number of issues, in particular, the problems of determining priorities for scientific and technical 
cooperation need further study and methodological elaboration. A theoretical, methodical, and integrated approach is needed for the formation of these priorities to determine the corresponding measures needed to implement them and increase innovation regarding the production and economic activities necessary for the use of non-conventional energy source technologies.

\section{Objective and method}

The objective of this article is the development of approaches for determining priorities of international scientific and technical cooperation in relation to the conditions of Ukraine, the EU and Chile that correspond to the needs of overcoming the crisis of this socio-economic phenomena based on the intensification of scientific and technical cooperation. Theoretical, methodological and logical methods of analyzing primary sources including statistical materials, regulatory documents and scientific publications for descriptive and structural analysis were used to assess the initial state of the basic level of scientific and technical cooperation within the framework of international economic relations and methods of forming trends in their development.

\section{Features and problems of the dynamics of innovation in Ukraine}

The systemic economic crises during the 90s, 2000s and 2013-2015 resulted in destructive changes in the scientific and industrial potential of Ukraine. The level of science and industry has decreased as well as a strong concern has arisen over the quality of education, which is based on objective (contradictory) trends (see Table 1.).

Table 1. The dynamics of the main scientific and production indicators of the Ukrainian economy, 2008 vs 2017

\begin{tabular}{|c|c|c|c|c|c|c|c|c|c|c|c|}
\hline No. & Year & 2008 & 2009 & 2010 & 2011 & 2012 & 2013 & 2014 & 2015 & 2016 & 2017 \\
\hline \multicolumn{12}{|c|}{ Indicators } \\
\hline 1 & $\begin{array}{l}\text { GDP (PPP), bln. } \\
\text { dol. }\end{array}$ & 405,2 & 346,5 & 351,6 & 378,5 & 386,4 & 392,6 & 373,4 & 340,6 & 353,3 & 368,7 \\
\hline 2 & $\begin{array}{l}\text { GDP per capita } \\
\text { (PPT), dol. }\end{array}$ & 8816 & 7569 & 7712 & 8328 & 8517 & 8676 & 8733 & 7997 & 8331 & 8713 \\
\hline 3 & $\begin{array}{l}\text { GDP growth } \\
\text { rate, \% }\end{array}$ & 2,2 & $-15,1$ & 0,3 & 5,5 & 0,2 & 0,1 & $-6,6$ & $-9,8$ & 2,4 & 2,5 \\
\hline 4 & $\begin{array}{l}\text { Unemployment } \\
\text { rate, \% }\end{array}$ & 6,4 & 8,8 & 8,1 & 7,9 & 7,5 & 7,2 & 9,3 & 9,1 & 9,3 & 9,4 \\
\hline 5 & $\begin{array}{l}\text { Number of } \\
\text { students, mln. } \\
\text { ppl. }\end{array}$ & 2,763 & 2,599 & 2,491 & 2,311 & 2,170 & 2,052 & 1,689 & 1,605 & 1,586 & 1,538 \\
\hline 6 & $\begin{array}{l}\text { Dynamics of } \\
\text { R\&D costs, \% of } \\
\text { GDP }\end{array}$ & 0,9 & 0,9 & 0,8 & 0,9 & 0,8 & 0,7 & 0,8 & 0,8 & 0,6 & 0,6 \\
\hline 7 & $\begin{array}{l}\text { Dynamics of } \\
\text { patent } \\
\text { applications, } \\
\text { pcs. }\end{array}$ & 2434 & 2825 & 2434 & 2556 & 2649 & 2491 & 2856 & 2457 & 2271 & 2233 \\
\hline 8 & $\begin{array}{l}\text { Articles in } \\
\text { scientific } \\
\text { journals, pcs. }\end{array}$ & 5489 & 5907 & 5633 & 6074 & 6400 & 6716 & 7450 & 7417 & 7455 & 7375 \\
\hline 9 & $\begin{array}{l}\text { Researchers in } \\
R \& D, \text { pal./mln. }\end{array}$ & 1432 & 1349,7 & 1332,2 & 1261,9 & 1234,7 & 1165,2 & 1026 & 1006 & 1008 & 992 \\
\hline
\end{tabular}

The following is a more detailed analysis of considered indicators.

1. During 2008-2016 Ukraine's GDP at current values, decreased by $\$ 94.8$ billion (50.4\%). During 2008-2016 the per capita GDP in Ukraine grew by $\$ 1,974.0$ (48.5\%) to $\$ 2,099.0$. The average annual decrease in per capita GDP at current values was $-\$ 246.8$ or $-8.0 \%$ (11). Ukraine's GDP in 2008 was equal to $\$ 188.1$ billion and ranked 45th 
in the world, near the same level as Singapore's GDP (\$192.2 billion) and Chile's GDP (\$179.6 billion). Compared to 2013, Ukraine's GDP fell from \$ 183.4 billion in 2013 to $\$ 112.1$ billion in 2017 [14].

2. Per capita GDP, even taking into account purchasing power parity (PPP) for 10 years has not shown any tendency to increase. In addition, the statistics of the Ukrainian population reveal many problematic issues. This includes immigration, Ukrainians working abroad, the total absence of a population census and other matters, which controversially reflect on this indicator.

3. Ukraine's total GDP, taking into account PPP for 10 years, decreased by $10 \%$. Moreover, during periods of crises (2008-2009, 2013-2015) there was a significant decrease. GDP growth was driven by the retail, nonmanufacturing sector. That is, weakly associated with innovative scientific and technological development. The table shows that Ukraine's GDP in 2010 showed an increase of $4.1 \%$ after a sharp drop of $-14.8 \%$ in 2009 . The change in the GDP of Ukraine in 2010-2014 was characterized by a significant growth of $4.1 \%$ and $5.2 \%$ (20102011 respectively) and minimal growth of $0.2 \%$ of Ukraine's GDP in 2012 and 2013. Ukraine's GDP in 2013 still held its positions, but from the end of the year up to the present, there has been a drop $(-6.8 \%-2014,-14.6 \%$ 2015) [15].

4. The unemployment rate for the period $2008-2017$ rose significantly by $46 \%$, which means a worsening of the crisis in the Ukrainian economy, while, despite some recovery in the Ukrainian economy after the 2014-2015 crisis, the unemployment rate in Ukraine remains high at 9,3\% in 2016 and 9.5\% in 2017 [16].

5. The main problem of higher education in Ukraine is that in $90 \%$ of cases it does not guarantee a high school graduate appropriate work in his/her specialty. Ukrainian higher education does not correspond to today's realities; it does not meet the demands of the labour market, the needs of the economy, and, most importantly, it does not meet the requirements of the students themselves. Up to $85 \%$ of university graduates in Ukraine do not work in the speciality that they acquired at university [17].

6.. According to the Global Competitiveness Index [18], the United States spends $\$ 405$ billion (up to $2.7 \%$ of GDP) on science annually followed by China, where research funding amounts to $\$ 338$ billion per year $(2.1 \%$ of GDP at purchasing power parity). Japan allocates $\$ 160$ billion (3.67\%) for this purpose. By way of comparison: in Ukraine during 2015, the budget for support research was 16 billion hryvnias (\$ 666 million), or only $0.8 \%$ of the GDP. In terms of the total investment in research Ukraine was ranked 76th in the world.

7. A decrease in patent applications from 2008 to 2017 in Ukraine was evident while the general tendency worldwide was an increase.

8. Against this background, the trend of growth of articles stands out separately. The main growth is in publications in foreign journals, which actually involves the use of intellectual resources to solve the problems of the development of advanced economies. However, during this time, the scope of application of intelligent products has significantly decreased in Ukraine.

9. The number of R \& D researchers in Ukraine for the period $2008-2017$ decreased by about $40 \%$. In fact, complex factors led to a reduction in GDP in general and per capita.

Based on the above conditions, scientific and technical cooperation with more developed scientific and production entities (for example, the EU) contributes to the migration of the intellectual resources of Ukraine from the direct emigration of Ukrainian scientists to the transfer of intellectual property directly to the scientific and production structures of the EU.

This is confirmed by the calculations of international innovation indices. The top ten Innovation Index, according to the data for the beginning of 2016, includes South Korea, Germany, Sweden, Japan, Switzerland, Singapore, Finland, the USA, Denmark and France. At the same time, South Korea's GDP grew by $2.3 \%$ last year, Germany by $1.7 \%$, Sweden - by $4.1 \%$, Singapore - by $2.1 \%$.

Ukraine is in 41st place, between Latvia and Bulgaria. Although, if the data of another annual study - the Global Innovation Index, is correct, Ukraine is in 64th place, between Serbia and the Seychelles. In 2013 Ukraine was in place 71, 2014 - 63, 2015 - 64, 2016 - 56, and 2017 - 50 [19]. 
Based on the above characteristics of the dynamics of factors of the scientific and production potential of Ukraine, in the authors' opinion, an interconnected analysis with the dynamics of the development of scientific and technical cooperation between Ukraine and the EU is needed. Table 2 presents data on the sustainable dynamics of the development of various programmes of scientific and technical cooperation Ukraine with the EU.

Table 2. The list of programmes in the framework of scientific and technical cooperation between Ukraine and the EU

\begin{tabular}{|c|c|c|}
\hline No. & Programme & Characteristics \\
\hline 1 & $\begin{array}{l}\text { FP7 - Seventh Framework } \\
\text { Programme for research } \\
\text { and technological } \\
\text { development }\end{array}$ & $\begin{array}{l}\text { There are two main strategic objectives of The Framework Programmes for } \\
\text { Research: } 1 \text {. to strengthen the scientific and technological base of European } \\
\text { industry; } 2 \text {. to encourage its international competitiveness, while promoting } \\
\text { research that supports EU policies. }\end{array}$ \\
\hline 2 & Erasmus Mundus & $\begin{array}{l}\text { This Programme aims to enhance quality in higher education through scholarships } \\
\text { and academic co-operation between the EU and other countries. Erasmus Mundus } \\
\text { comprises three actions: } 1 \text {. Joint programmes. } 2 \text {. Partnerships. 3. Attractiveness } \\
\text { projects. }\end{array}$ \\
\hline 3 & Tempus & $\begin{array}{l}\text { The Tempus Programme finances interuniversity cooperation in the field of } \\
\text { development and improvements of curricula, university governance, interaction } \\
\text { between academics and civil society, cooperation between education and business, } \\
\text { as well as structural reforms in higher education. }\end{array}$ \\
\hline 4 & $\begin{array}{l}\text { TACIS (Technical } \\
\text { Assistance to the } \\
\text { Commonwealth of } \\
\text { Independent States and } \\
\text { Georgia) }\end{array}$ & $\begin{array}{l}\text { The objective of the programme is to help individual states to develop effectively- } \\
\text { functioning market economies based on private ownership and initiative, and to } \\
\text { encourage the development of pluralistic democratic societies. }\end{array}$ \\
\hline 5 & $\begin{array}{l}\text { Jean Monnet Programmed } \\
\text { under the Lifelong Learning } \\
\text { Programme }\end{array}$ & $\begin{array}{l}\text { The European Commission's Lifelong Learning Programme enables people at all } \\
\text { stages of their lives to take part in stimulating learning experiences, as well as } \\
\text { helping to develop the education and training sector across Europe. }\end{array}$ \\
\hline 6 & $\begin{array}{l}\text { INSC - Instrument for } \\
\text { Nuclear Safety Cooperation } \\
\text { (from } 2007 \text { onward since it } \\
\text { replaces the Tacis Nuclear } \\
\text { Safety Programme) - } \\
\text { funded though ENPI } \\
\text { European Neighborhood } \\
\text { and } \\
\text { Instrument Partnership }\end{array}$ & $\begin{array}{l}\text { Via the INSC the following specific objectives are: 1.The promotion of an effective } \\
\text { nuclear safety culture and implementation of the highest nuclear safety and } \\
\text { radiation protection standards, and continuous improvement of nuclear safety. } 2 \text {. } \\
\text { Responsible and safe management of spent fuel and radioactive waste and } \\
\text { remediation of former nuclear sites and installations. 3.The establishment of } \\
\text { frameworks and methodologies for the application of efficient and effective } \\
\text { safeguards for nuclear material in third countries }\end{array}$ \\
\hline 7 & $\begin{array}{l}\text { ENPI CBC (Cross-Border- } \\
\text { Cooperation) Poland- } \\
\text { Belarus-Ukraine } \\
\text { Programme }\end{array}$ & $\begin{array}{l}\text { For } 15 \text { years supports the cross-border development processes in the borderland } \\
\text { of Poland, Belarus and Ukraine by co-funding diverse projects. All projects funded } \\
\text { within the Programme are non-profit ones and contribute to the improvement of } \\
\text { quality of life of inhabitants of eastern Poland and western Ukraine and Belarus. }\end{array}$ \\
\hline 8 & $\begin{array}{l}\text { Hungary-Slovakia- } \\
\text { Romania-Ukraine ENPI } \\
\text { Cross-border Cooperation } \\
\text { Programme 2007-2013 }\end{array}$ & $\begin{array}{l}\text { This Programme offers a wide range of opportunities to potential Beneficiaries } \\
\text { through four priorities - Economic and social development, enhancement of } \\
\text { environmental qualities, increased border efficiency and support for people to } \\
\text { people cooperation. }\end{array}$ \\
\hline 9 & $\begin{array}{l}\text { Joint } \quad \text { Operational } \\
\text { Programme Romania- } \\
\text { Ukraine-Republic } \quad \text { of } \\
\text { Moldova 2007-2013 }\end{array}$ & $\begin{array}{l}\text { Is a cooperation programme financed by the European Union through the } \\
\text { European Neighbourhood and Partnership Instrument 2007-2013. The programme } \\
\text { aims to create "bridges" among the three countries involved, in order to help the } \\
\text { border areas overcome their similar development challenges, by working together } \\
\text { and finding common solutions }\end{array}$ \\
\hline 10 & Euroatom & $\begin{array}{l}\text { Euratom aims to pursue nuclear research and training activities with an emphasis } \\
\text { on continually improving nuclear safety, security and radiation protection, notably } \\
\text { to contribute to the long-term decarbonisation of the energy system in a safe, } \\
\text { efficient and secure way. }\end{array}$ \\
\hline 11 & Eurostudent VI & $\begin{array}{l}\text { The main aim of the EUROSTUDENT project is to collate comparable data on the } \\
\text { social dimension of European higher education. } \\
\text { It focuses on the socio-economic background and on the living conditions of } \\
\text { students, but it also investigates temporary international mobility. }\end{array}$ \\
\hline 12 & Horizon 2020 & $\begin{array}{l}\text { Horizon } 2020 \text { is the biggest EU Research and Innovation programme. It is the } \\
\text { financial instrument implementing the Innovation Union, a Europe } 2020 \text { flagship } \\
\text { initiative aimed at securing the global competitiveness of Europe. }\end{array}$ \\
\hline
\end{tabular}




\begin{tabular}{|c|c|c|}
\hline 13 & COSME & $\begin{array}{l}\text { The programme for the Competitiveness of Enterprises and Small and Medium- } \\
\text { sized Enterprises is improving access to finance for SMEs. }\end{array}$ \\
\hline 14 & $\begin{array}{l}\text { Black Sea } \\
\text { Opasin Joint } \\
\text { Operational Programme } \\
2007-2013\end{array}$ & $\begin{array}{l}\text { There are } 8 \text { participating countries in the Black Sea JOP, i.e. Armenia, Bulgaria, } \\
\text { Georgia, Moldova, Turkey, Ukraine, Romania, and Greece. } \\
\text { The Black Sea JOP aims at creating a stronger and more sustainable economic and } \\
\text { social development of the Black Sea Basin regions. }\end{array}$ \\
\hline 15 & $\begin{array}{l}\text { INOGATE Interstate Oil and } \\
\text { Gas Transport to Europe - } \\
\text { funded though ENPI } \\
\text { European Neighborhood } \\
\text { and } \\
\text { Instrument }\end{array}$ & $\begin{array}{l}\text { The international energy co-operation programme between the European Union, } \\
\text { the littoral states of the Black \& Caspian Seas and their neighbouring countries, } \\
\text { which have agreed to work together toward the achievement of the following four } \\
\text { major objectives: } 1 \text {.Converging energy markets on the basis of the principles of the } \\
\text { EU internal energy market taking into account the particularities of the involved } \\
\text { countries. 2. Enhancing energy security by addressing the issues of energy } \\
\text { exports/imports, supply diversification, energy transit and energy demand. 3. } \\
\text { Supporting sustainable energy development, including the development of energy } \\
\text { efficiency, renewable energy and demand side management. 4. Attracting } \\
\text { investment towards energy projects of common and regional interest. }\end{array}$ \\
\hline 16 & $\begin{array}{lr}\begin{array}{l}\text { Nuclear } \\
\text { operation }\end{array} & \text { Safety } \quad \text { Co- } \\
\text { (NSCl) } & \text { Instrument }\end{array}$ & $\begin{array}{l}\text { An Instrument to support the promotion of a high level of nuclear safety, radiation } \\
\text { protection and the application of efficient and effective safeguards regarding } \\
\text { nuclear material in third countries. }\end{array}$ \\
\hline 17 & $\begin{array}{l}\text { South East Europe } \\
\text { Programme }\end{array}$ & $\begin{array}{l}\text { This programme aims to develop transnational partnerships on matters of strategic } \\
\text { importance, in order to improve the territorial, economic and social integration } \\
\text { process and to contribute to the cohesion, stability and competitiveness of the } \\
\text { region. For this purpose, the Programme seeks to realize high quality, result- } \\
\text { oriented projects of strategic character, relevant for the programme area. }\end{array}$ \\
\hline 18 & Central Europe Programme & $\begin{array}{l}\text { This programme aims to improve capacities for regional development in } \\
\text { innovation, carbon dioxide level reduction, the protection of natural and cultural } \\
\text { resources as well as transport and mobility. }\end{array}$ \\
\hline
\end{tabular}
Source: [20]

In our opinion, the growth dynamics of programmes should be compared with the dynamics of the main scientific and production indicators of Ukraine. The main trends are presented in Figure 1.

From Figure 1, it is clear that against the background of the growth of the dynamics of various programmes within the framework of scientific and technical cooperation between Ukraine and the EU, there is a tendency to reduce the basic economic, scientific and technical indicators. Thus, we can conclude that, as of 2018, that the growth trends of the scientific and production potential of Ukraine does not confirm the trend of strengthening this vector, and in fact, there is a downward trend. 


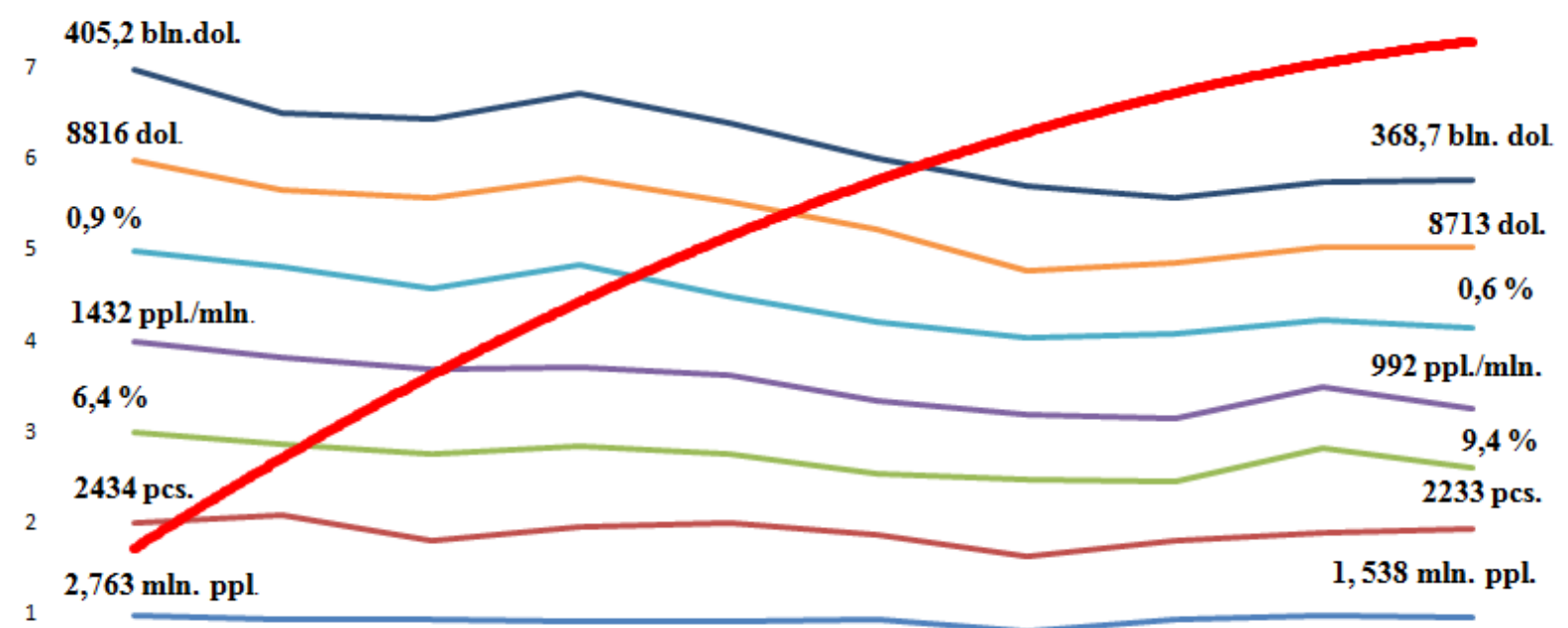

\begin{tabular}{llllllllll}
\hline 2008 & 2009 & 2010 & 2011 & 2012 & 2013 & 2014 & 2015 & 2016 & 2017
\end{tabular}

$\begin{array}{ll}\text { - Number of students, mln. ppl. (1) } & \text { Dynamics of patent applications, pcs. (2) } \\ \text { - Unemployment rate, \% (3) } & \text { Researchers in R\&D, ppl./mln. (4) } \\ \text { - Dynamics of R\&D costs, \% of GDP (5) } & \text { GDPper capita (PPT), dol. (6) } \\ \text { - GDP(PPP), bln. dol. (7) } & \text { Scientific and Technical Cooperation Trend }\end{array}$

Figure 1. Comparative characteristics of the relationship between the growth of scientific and technical cooperation programs between Ukraine and the EU and the main trends in the development of the Ukrainian economy Source: Author' materials based on Table 1

Nowadays, there is a growing increase in the share of energy source generation from renewable sources. Since the 2000s, this trend in the development of this energy sector has become more and more stable and is projected to continue to increase in the coming decades. Systemic oil and gas crises, the complication of international political relations in the struggle for energy resources and the emergence on the energy markets of innovative investors such as Apple, Microsoft, Google and Elon Musk with his SolarCity have helped contribute to this [21]. All this has given a significant impetus to the dynamic development of the global market for renewable energy sources, including the EU, in which these stable prerequisites indicate its strengthening in the foreseeable future. Consequently, today the global market for renewable energy sources is developing dynamically (see Figure 2), and there are no serious prerequisites indicating a change in this trend in the future. A positive point is that Ukraine has responded to the trend reflected in Table 3.

In our opinion, there is ae need for Ukraine to seriously consider the development experience of nonconventional renewable energy in the EU. Along with this, there is a need to make a comparative study of the positive results of non-conventional renewable energy usage in other developing and poor countries, which are also being reformed according to the priorities of the development of world experience of non-conventional renewable energy technologies.

Determining priorities of scientific and technical cooperation between Ukraine and Chile in the field of nonconventional renewable energy technologies

Considering the conditions of the modern innovative economy, economic relations may have a priority not as much in commodity items, but in intellectual and organizational communication systems of their realization. This relates to the exchange of experience, licenses, know-how and rapid expansion of scientific, technical and technological cooperation. It is through these means that it is possible to solve the issues of raising the technological level of various industries and the national economy as a whole such as the needed tasks of accelerated technological re-equipment, the need to expand export opportunities and reduce imports and need 
to develop technical and economic ties between countries based on specialization and cooperation in the production of various types of products [22].

One of the potential areas is the exchange of experience, knowledge and technologies in the field of the formation and implementation of the strategy for the development of non-conventional renewable energy (NCRE). For this, the prerequisites are considered according to the following reasons:

- both in Ukraine and in Chile there are various climatic conditions that have potential for the development of certain types of NCRE;

- both in Ukraine and in Chile there are sufficient potential sources of NCRE;

- both Ukraine and Chile have a comparable research and production potential that can be used to implement NCRE technologies;

- during the same period, both Ukraine and Chile have embarked on the path of development of NCRE since the 2000s.

However, as presented in Table 3, the growth rate of NCRE in Chile is significantly higher than in Ukraine.

The table shows that in Chile, the growth rate of NCRE generation based on solar, wind energy and bioenergy is much higher than in Ukraine as illustrated in Figure 2 below.

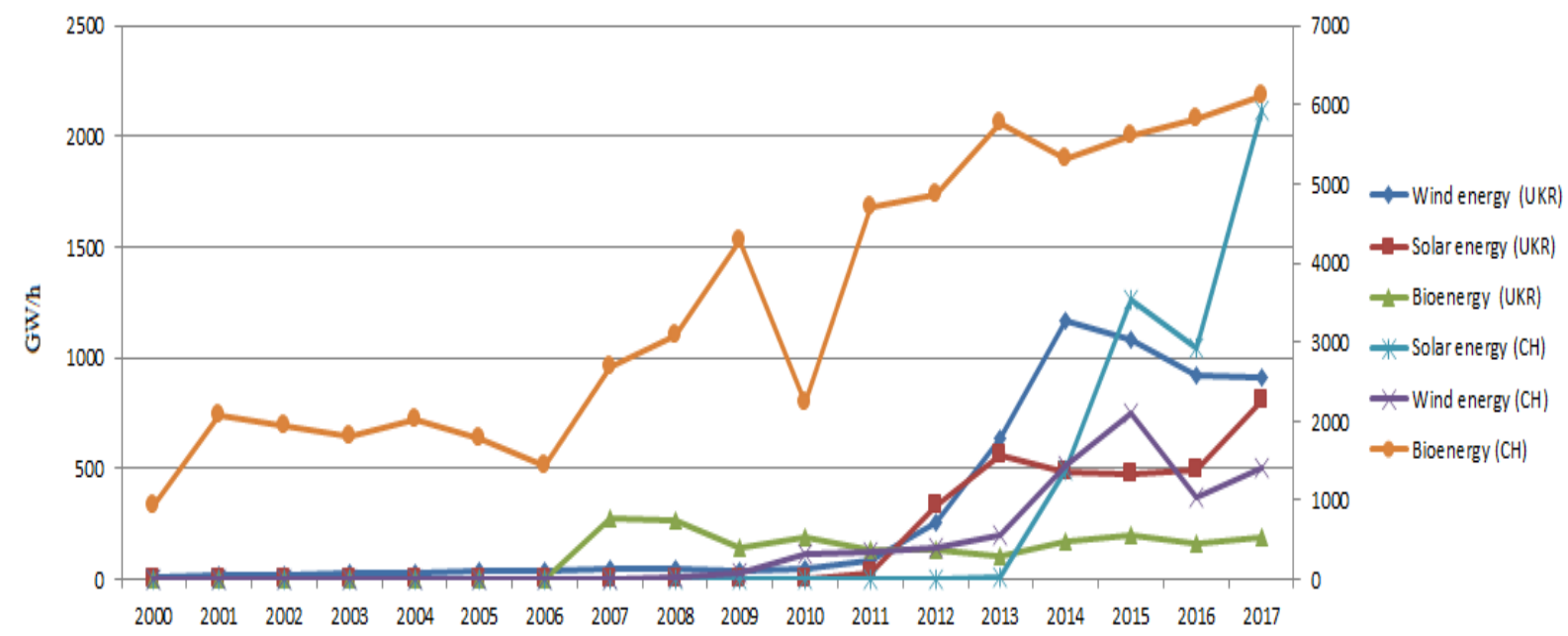

Figure 2 Comparative dynamics of energy production from various NCRE sources in Chile and Ukraine for 2000-1017 Source: Author's based on [15, 23-27] 
Table 3. Dynamics of actual energy production from NCRE (2000-2017) in Ukraine / Chile, GW/h

\begin{tabular}{|c|c|c|c|c|c|c|c|c|c|c|c|c|c|c|c|c|c|c|c|}
\hline NCRE sources & 2000 & 2001 & 2002 & 2003 & 2004 & 2005 & 2006 & 2007 & 2008 & 2009 & 2010 & 2011 & 2012 & 2013 & 2014 & 2015 & 2016 & 2017 & $\begin{array}{c}\text { Growth } \\
\text { rate }\end{array}$ \\
\hline \multirow[t]{2}{*}{ Wind energy } & 6 & 16 & 22 & 31 & 33 & 38 & 35 & 45 & 45 & 41 & 49 & 89 & 258 & 637 & 1172 & 1084 & 924 & 915 & 152,5 \\
\hline & 0 & 7 & 7 & 7 & 7 & 7 & 7 & 9 & 38 & 79 & 332 & 338 & 409 & 554 & 1443 & 2114 & 491 & 804 & 202,7 \\
\hline \multirow[t]{2}{*}{ Solar energy } & 0 & 0 & 0 & 0 & 0 & 0 & 0 & 0 & 0 & 0 & 1 & 30 & 334 & 563 & 483 & 475 & 164 & 190 & 26,8 \\
\hline & 0 & 0 & 0 & 0 & 0 & 0 & 0 & 0 & 0 & 0 & 0 & 0 & 0 & 8 & 490 & 1261 & 1029 & 1419 & 264,4 \\
\hline \multirow[t]{2}{*}{ Biomass energy } & 0 & 0 & 0 & 0 & 0 & 0 & 0 & 281 & 264 & 139 & 188 & 134 & 134 & 106 & 169 & 199 & 1041 & 2115 & 0,7 \\
\hline & 941 & 2068 & 1944 & 1807 & 2031 & 1790 & 1431 & 2696 & 3083 & 4274 & 2249 & 4703 & 4874 & 5761 & 5327 & 5615 & 5812 & 6124 & 6,5 \\
\hline \multirow[t]{2}{*}{$\begin{array}{l}\text { Total NCRE } \\
\text { production }\end{array}$} & 6 & 16 & 22 & 31 & 33 & 38 & 35 & 326 & 309 & 180 & 238 & 253 & 726 & 1306 & 1824 & 1758 & 1579 & 1909 & 119,3 \\
\hline & 941 & 2075 & 1951 & 1814 & 2038 & 1797 & 1438 & 2705 & 3121 & 4353 & 2581 & 5041 & 5283 & 6323 & 7260 & 8990 & 7882 & 9658 & 8,8 \\
\hline \multirow[t]{2}{*}{$\begin{array}{l}\text { Average NCRE } \\
\text { production }\end{array}$} & 2 & 5,3 & 7,3 & 10,3 & 11 & 12,6 & 11,6 & 109 & 103 & 60 & 79,3 & 84,3 & 242 & 435 & 608 & 586 & 526 & 636 & \\
\hline & 314 & 692 & 650 & 605 & 679 & 599 & 479 & 902 & 1040 & 1451 & 860 & 1680 & 1761 & 2108 & 2420 & 2996 & 2627 & 2746 & \\
\hline
\end{tabular}


In the process of analysis, the dynamics of average values and trends of total indicators of NCRE production of Chile and Ukraine show the field of growth of potential innovative susceptibility to NCRE technologies in the process of mutual scientific and technical cooperation between the subjects of international economic relations.

To justify the prospects of international cooperation between Ukraine and Chile, we made an analysis of the comparative dynamics of the volume of NCRE production. Based on these sources, there are comparative figures for the period from 2000 to 2017. According to Table 3, graphs presented in Figure 2 clearly reflect the dynamics of these processes. As the starting conditions for the development of NCRE were relatively similar, then considering the entire period, we can conclude that the growth rates of various types of renewable energy in Chile significantly exceed those in Ukraine.

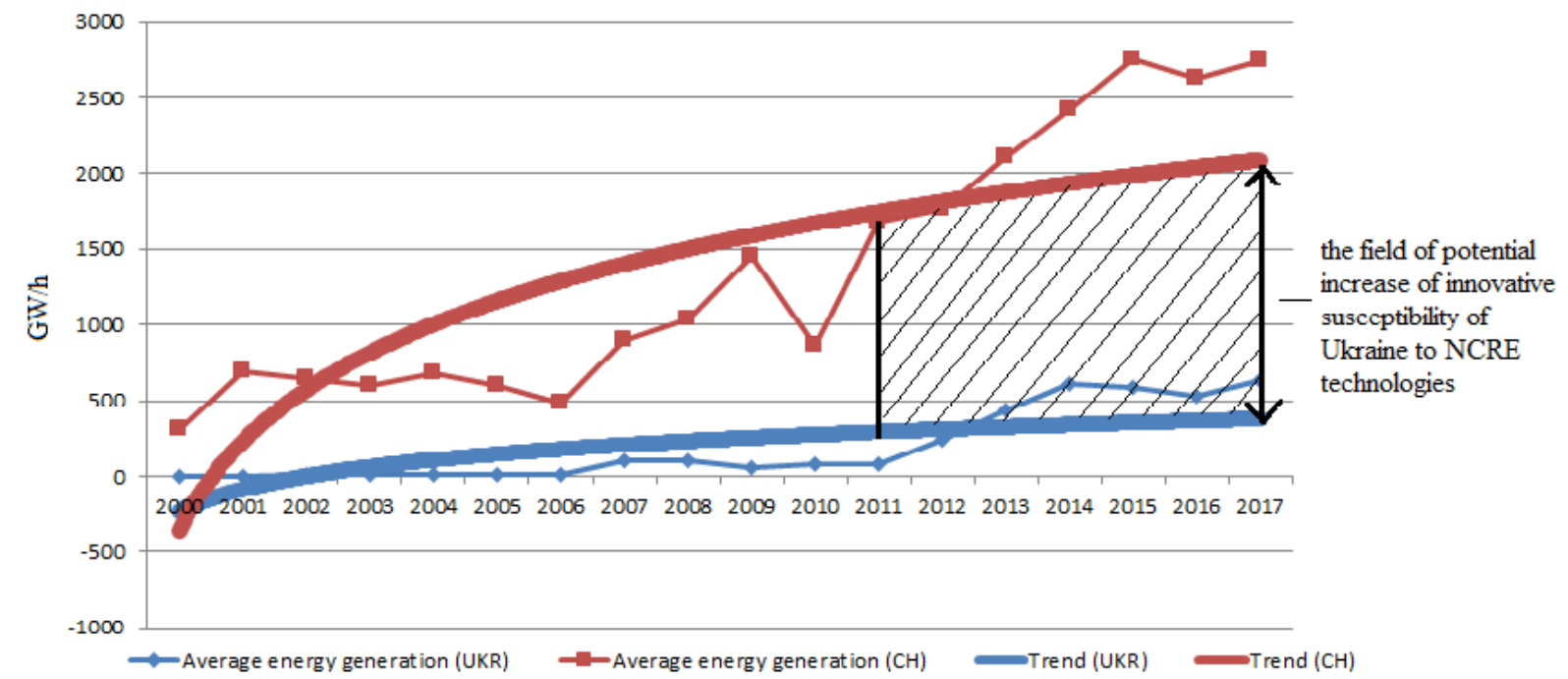

Figure 3 Dynamics of average values, trends in NCRE production over the years (2000-2017) and the growth prospects of innovative susceptibility to NCRE in the process of scientific and technical cooperation between Chile and Ukraine Source: Author's materials based on [15, 23-27]

By the analysis of the comparative dynamics of trends in NCRE production, we can conclude that the Chilean dynamics substantially exceed those of Ukraine, which implies the need of a corresponding analysis of the conditions and forms of state support for these processes. Figure 2 presents the interpretation of the dynamics of NCRE development based on mathematical methods, in particular the logarithmic smoothing of graphs and their corresponding transformations into averaged trends. This made it possible to graphically visualize the field of potential innovative susceptibility of the development of the use of NCRE technologies by business entities in Ukraine.

This field of innovative susceptibility represents a segment of the innovative information for the formation of priorities in the international scientific and technical cooperation in the field of NCRE. In particular, regarding the current issues of convergent technologies, it also touches upon the issues of NCRE in terms of using elements of NBIC technologies within its framework. Among them, attention should be paid to:

1. Whether any party has elements of NBIC-technologies in the field of NCRE, then this immediately becomes a priority of international cooperation.

2. In fact, NCRE technologies already use elements of NBIC technologies. For example, solar collectors have the prospect of using nano-coatings and biotechnologies provide unconventional energy generation technologies from organic waste.

3. A promising direction from the point of view of NBIC is the creation of energy-saving complexes based on a combination of generating technologies on a traditional and non-traditional basis. This is especially important for improving the efficiency of existing traditional energy generation [28].

For example, it is possible that energy-saving complexes based on, for example, a house gas boiler, may systematically include a solar power system and a heat pump, which as experience has shown, will allow a reduction of the average annual consumption of fossil fuels by $40 \%$. At the same time, elements of NBIC technologies are being used to some extent. All this shows serious scientific production and organizational- 
economic prerequisites for the formation of the priorities of scientific and technical cooperation between Ukraine and Chile in the field of NCRE.

\section{Conclusions}

On the basis of a phased analysis of the formation of priorities for development in Ukraine, we propose an approach for analysing the integrated development of national economies. This will allow a more reasonable approach to the selection of priorities for intergovernmental cooperation, including the growth of relevant areas of development. The results of the analysis, within the framework of interstate cooperation between Ukraine and the EU, allow to determine promising directions for development the field of NCRE sources between Ukraine and Chile. The author's exploration of cooperation of Ukraine with Chile in the field of green energy has proven that such cooperation is possible from the example of successful scientific and technical cooperation between Ukraine and the EU countries. In general, in Ukraine the development of certain areas of NCRE (such as solar and wind power) began within the framework of world trends (including the EU) much earlier than in Chile. However, until now there have been no institutional changes in the attitude towards NWE technologies in Ukraine [20].

In Chile, during 2007 - 2017, institutional changes occurred in the sphere of innovation susceptibility to NCRE technologies, which affected a wide range of factors, including political, legal, and socio-economic factors. Separately, it is possible to single out a complex of factors of scientific and technical cooperation with various advanced actors of the global economy on the issue of NCRE.

Accordingly, within the framework of world development, including trends in the EU, there is a prospect for the development of scientific and technical cooperation between Chile and Ukraine on NCRE issues, including:

1. The formation of priorities and the role of state programs of scientific and technical cooperation in the development of the national economies.

2. Organisational and economic forms of scientific and technical cooperation in the field of NCRE between Chile and Ukraine taken from the example of such cooperation between Ukraine and the EU.

3. The experience of state support of the subjects of the producer-consumer NCRE cycle, taking into account the best international practices, including the EU.

4. Forms of development of producer and consumer motivation; selection of the priorities for NCRE technologies taking into account the experience of advanced economies, including EU countries.

5. Exchange of intellectual products (technology, licenses, know-how, etc.).

\section{References}

[1] V. Dyuzhev, Organizational and economic problems of increasing innovative sustainability to technologies of non-traditional renewable energy in Ukraine, monograph, Kharkiv, 2012, pp. 36-39.

[2] V. Sidorov, T. Revyakin, The impact of globalisation on the synchronization of economic processes within the world economy, jrnl. Business Inform, ed. 3, 2017, pp. 16-20.

[3] V. Babenko, Aspects of program control over technological innovations with consideration of the risks, Eastern-European jrnl. Of Enterprise Techs, Vol. 3/4 (93), 2018, pp. 6-14. DOI: 10.15587/17294061.2018.133603 (Scopus) https://www.researchgate.net/publication/326688994 133603-292656-1$\underline{\mathrm{PB}}$

[4] V. Babenko, N. Chebanova, N. Ryzhikova, S. Rudenko, N. Birchenko, Research into the process of multilevel management of enterprise production activities with taking risks into consideration, European Journal of Enterprise Technologies. Vol. 1, No 3 (91), 2018. DOI: 10.15587/1729-4061.2018.123461

[5] V. Babenko, O. Nazarenko, I. Nazarenko, O. Mandych, Aspects of programme control over technological innovations with consideration of risks, Eastern-European Journal of Enterprise Technologies. Vol. 3/4 (93), 2018. DOI: 10.15587/1729-4061.2018.133603

[6] V. Sidorov, V. Babenko, M. Bondarenko, Researching factors of innovative activities of agrarian business of Ukraine under globalization of the world economy. Innovative technologies and scientific solutions for industries, No. 2 (2), 2017. DOI: https://doi.org/10.30837/2522-9818.2017.2.070 URL: http://itssijournal.com/index.php/ittsi/article/view/33

[7] I. Matyushenko, S. Berenda, V. Reznikov, European integration of Ukraine into the system of international $\begin{array}{llll}\text { economic } \quad \text { integration: } & \text { tutorial, } & 496 & \text { p., }\end{array}$ https://www.researchgate.net/profile/Igor Matyushenko/publication/314044799 EUROPEAN INTEGR ATION OF UKRAINE INTO THE SYSTEM OF INTERNATIONAL ECONOMIC INTEGRATION TUTORIAL/Li 
nks/58b1f2b992851cf7ae8ee045/EUROPEAN-INTEGRATION-OF-UKRAINE-IN-THE-SYSTEM-OFINTERNATIONAL-ECONOMIC-INTEGRATION-TUTORIAL.pdf

[8] V. Dyuzhev, Theoretical and methodical bases of the increase of innovative companies to the susceptibility of non-traditional renewable energy technologies, theses. National Technical University "Kharkiv Polytechnical Institute", Kharkiv, 2016.

[9] S. Voitko, K. Volynets, Research of the dynamics of volumes of investing is in alternative energy by sectors and regions, jrnl. Economic Forum 1/2017, pp. 58-63.

[10] V. Dzhedzhula, Management of alternative energy sources in the system of innovative development of enterprises, monograph, Process and socially competent management of innovative development of business system, pp.

$146-155$ https://ir.lib.vntu.edu.ua/bitstream/handle/123456789/19758/\%D0\%94\%D0\%B6\%D0\%B5\%D0\%B4\%D0 \%B6\%D1\%83\%D0\%BB\%D0\%B0 \%D0\%BC\%D0\%BE\%D0\%BD\%D0\%BE\%D0\%B3\%D1\%80\%D0\%B0\%D1\%84 \%D1\%96\%D1\%8F 2017 \%D0\%9B\%D1\%83\%D1\%86\%D1\%8C\%D0\%BA.pdf?sequence=1\&isAllowed=y

[11] O. Vytvytska, E. Buzovskii, Innovative components of alternative energy, scient. jrnl. NUBiP of Ukraine, 3 (\#177), 2012, pp. 102-107.

[12] I. Matyushenko, I. Buntov, O. Khanova, The next economy in Ukraine: developing alternative energy with the help of NBIC-technologies.British Journal of Economics, Management \& Trade, United Kingdom, London; USA, Wilmington; India, Gurgaon, 9 (2), 2015, pp. 1-19 http://international-relationstourism.karazin.ua/themes/irtb/resources/5e4bd79f3b576599caafef4e25a3c546.pdf

[13] Knoema Corporation (US). https://knoema.com/

[14] I. Kushnir Institute of Economics and Law. http://be5.biz/makroekonomika/gdp/ua.html

[15] State Statistics Service of Ukraine. http://www.ukrstat.gov.ua/

[16] BusinessViews, Casual business insights. https://businessviews.com.ua/ru/economy/id/ekonomikaukrainy-v-2018-1786/

[17] S. Valovenko, Higher education in Ukraine - the path to the unknown. / GolosUA, 2017. https://golos.ua/i/560097

[18] The Global Competitiveness Report 2017-2018. http://www3.weforum.org/docs/GCR20172018/04Backmatter/TheGlobalCompetitivenessReport2017\%E2\%80\%932018AppendixB.pdf

[19] Global Innovation Index. https://www.globalinnovationindex.org/analysis-indicator

[20] European Comission.

http://ec.europa.eu/geninfo/query/index.do?QueryText=ukraine\&op=Search\&swlang=en\&form build i $\mathrm{d}=$ form-

Khe jSOhgU6nNeD3Dr2iWFiy4lo3sH25OSb27KDKqxk\&form id=nexteuropa europa search search for $\underline{\mathrm{m}}$

[21] Eco Technologies, How Ukraine reorienting to the development of renewable energy sources and replacement of fossil fuels, 2016. https://ecotechnica.com.ua/stati/1730-kak-ukrainepereorientirovatsya-na-razvitie-vozobnovlyaemykh-istochnikov-energii-i-zameshchenie-iskopaemogotopliva.html

[22] R. Sklyarenko, Regulation of the presence of states in the world technology market, theses, Moscow, 2014. http://www.sciteclibrary.ru/texsts/rus/stat/st1336.htm

[23] International Renewable Energy Agency, Renewable Energy Statistics 2017. http://www.irena.org//media/Files/IRENA/Agency/Publication/2017/Jul/IRENA Renewable Energy Statistics 2017.pdf

[24] Comision Nacional de Energia, Reporte Sector Energetico Enero 2017, Volumen \#23, Enero 2017 http://www.revistaei.cl/wp-content/uploads/sites/5/2017/01/RMensual_v201701.pdf

[25] Comision Nacional de Energia, Reporte Sector Energetico Diciembre 2017, Volumen \#17, Diciembre 2017. http://www.revistaei.cl/wp-content/uploads/sites/5/2017/12/Bolet\%C3\%ADn-Generaci\%C3\%B3nDiciembre-2017.pdf

[26] Ukraine Sustainable Energy Lending Facility (USELF). http://www.uself.com.ua/index.php?id=28\&L=ftp\%3A\%2F\%2Fhappyh\%3Ah\%40pPiRs2\%4080.74.155.20\%2Fhttpsdocs\%2Fx-men.php\%3F \%20\%27\%20

[27] Ministerio de Energia. http://www.energia.gob.cl/

[28] I. Matyushenko, Prospects for the development of convergent technologies in the countries of the world and Ukraine for solving global problems: monograph, Kharkiv: Sole Proprietor L. M. Liburkina, 448 p. 